\title{
ECONOMIC MECHANISM OF OPTIMIZING THE INNOVATION INVESTMENT PROGRAM OF THE DEVELOPMENT OF AGRO-INDUSTRIAL PRODUCTION
}

\section{Katarina Brockova ${ }^{1}$, Volodymyr Rossokha ${ }^{2}$, Vitalii Chaban ${ }^{3}$, Mykola Zos-Kior $^{4}$, *Iryna Hnatenko ${ }^{5}$, Viktoriia Rubezhanska ${ }^{6}$}

\author{
${ }^{1}$ Assoc. Prof. PhD. University of Economics in Bratislava. Dolnozemská cesta 1. 852 35. Bratislava. Slovakia. \\ E-mail address katarina.brockova@euba.sk
}

${ }^{2}$ Prof. Dr Sc. National Scientific Centre, Institute of Agrarian Economics. Heroiv Oborony str.10. 03127. Kyiv. Ukraine. E-mail address rossokha@ukr.net

${ }^{3}$ Assoc. Prof. PhD. Kyiv National Economic University named after Vadym Hetman. Peremohy Ave 54/1. 03057. Kyiv. Ukraine. E-mail address pokeragro3@gmail.com

${ }^{4}$ Prof. Dr Sc. Poltava State Agrarian Academy. Skovoroda str. 1/3. 36003. Poltava. Ukraine.

E-mail addresszoskior@gmail.com

${ }^{5}$ Assoc. Prof. Dr Sc. Kyiv National University of Technologies and Design. Nemyrovycha-Danchenka str. 2. 01011. Kyiv. Ukraine.E-mail addressq17208@ukr.net

${ }^{6}$ PhD. Luhansk Taras Shevchenko National University. Gogol str. 1. 92700. Starobilsk. Ukraine. E-mail address rubezhiik@gmail.com

Received 2801 2021; Accepted 01032021

\begin{abstract}
The progressive activity of agro-industrial production in the context of imperfect competition, turbulence of the environment and unexpected market challenges in the agro-industrial market because of spread of COVID-19 should be ensured by the most effective selection of the optimal innovation and investment program. Such program must be adapted to the realities of today, provide effective innovation projects and financial resources for their implementation support. This can be achieved due to the formation of a comprehensive innovation and investment program for multidirectional projects taking into account the required amount of money at all stages of risky innovative activities implementation. In this regard, the aim of the article is to conceptualize the implementation of the innovation and investment program in the activities of agro-industrial enterprises using an adaptive model of the optimal selection of the most effective projects or diversification of existing ones and planning their intrusion into the consumer market by choosing the optimal financial strategy for innovation support. To achieve the aim, the following methods were used: observation, system analysis, economic and mathematical and experimental modeling, abstract-logical and graphical method. The economic and mathematical model developed by the authors can be used in the practical activity of agro-industrial enterprises. This model enables to determine a promising strategy of innovative development and form the target programs for their financial support under conditions of limited resources and market changes in agriculture.
\end{abstract}

Keywords: economic mechanism, optimization, innovation-investment program, the development of agro-industrial production, innovative project, investments, economic-mathematical model, economic effect, cash flow, target function. JEL Codes: D24, O32.

\section{Introduction}

The unfavorable trends, caused by the introduction of quarantine measures against the rapid spread of COVID-19 affects agriculture and the food market. Agro- industrial enterprises are faced with difficulties in selling their own products due to the transport restrictions, reduced incomes, increased prices for fuel and lubricant, closing of borders for seasonal workers who involved in agriculture that can lead to a decrease in food security and a reduction in national reserves of agricultural products (Hnatenko,

Copyright (C 2021 Author(s), published by Vytautas Magnus University. This is an open access article distributed under the terms of the Creative Commons Attribution Non-Commercial 4.0 (CC BY-NC 4.0) license, which permits unrestricted use, distribution, and reproduction in any medium provided the original author and source are credited. The material cannot be used for commercial purposes. 
Orlova-Kurilova, Shtuler, Serzhanov, Rubezhanska, 2020; Zos-Kior, Hnatenko, Isai, Shtuler, Samborskyi, Rubezhanska, 2020). The pandemic and introduction of lockdowns have caused a global crisis and recession, even in highly developed countries of the world: Italy, Great Britain, Japan, Singapore, South Korea, Germany, Poland, Lithuania, Estonia, Latvia, etc. In this context, the globalization of the world food market further intensifies fierce competition between agro-industrial enterprises in some countries that demands the development of such a strategy of consolidation in agrobusiness and agricultural trade, which would best help businesses to create new, update existing innovative products (works, services) and to promote further intrusion into the consumer market.

Thus, conceptualization of implementation of the innovation and investment program in the activities of agroindustrial enterprises involves continuous attraction of the necessary funding sources for innovations, production diversification and intrusion of the developed innovations into the market in order to quickly upgrade agrarian business (Goncharov, Zos-Kior, Rakhmetulina, 2013).

The scientific works of many scientists are devoted to the study of selection of optimal innovative projects, as well as the ensuring of necessary funding for their successful implementation. Thus, Stevanato, Lombardi, Guidicini, Rinaldi, Balderrama, Pavičević, Quoilin, Colombo (2020) formulated a mathematical model of long-term optimization. It is able to predict the necessary investment decisions in order to expand the capacity of agro-industrial enterprises. Martins (2017) offered a mathematical model of linear programming aimed at maximizing cash flow in the implementation of innovative projects in the agro-industrial sector. GanushchakEfimenko, Hnatenko, Kozhushko, Rębilas, Rubezhanska, Krakhmalova (2020) considered ways to optimize an investment management model of innovative agricultural enterprises. Scientific works of Shahbaz, Raghutla, Song, Zameer, Jiao (2020) and Cardoso, Gonçalves, Carvalho (2020) showed the importance of projects on the introduction of various types of innovations for the agro-industrial production development. Liu, Wang, Chan, Fung (2020) investigated how financial literacy of entrepreneurs affects the effectiveness of their investment decisions on the development and implementation of innovations in agriculture. Luo, Guo, Jia (2017) analyzed the impact of innovations in the production processes of agricultural enterprises on the financial performance of business entities in the agroindustrial sector of China. Galliano, Gonçalves, Triboulet (2019) studied the specific character of the functioning of peripheral eco-innovation systems and the peculiarities of their investment support at agro-industrial enterprises in France. The article of Collins, Reutzel (2017) investigated the role of top managers in effective innovation and investment activities of small and medium-sized enterprises in India. Zos-Kior, Hnatenko, Isai, Shtuler, Samborskyi, Rubezhanska (2020) proposed methods for assessing the economic efficiency of innovative projects on energy and resource saving.

It is necessary to admit the need for further research to optimize the choice of appropriate innovative projects, as well as their financial support, production diversification and the developed innovations intrusion into the market. In this regard, the aim of the research is to conceptualize implementation of the innovation and investment program in the activities of agro-industrial enterprises using an adaptation model for the optimal selection of the most effective projects or diversification of existing ones and planning their intrusion into the consumer market by choosing the optimal financial strategy for innovative activity support.

The object of the research is the specific character of the functioning of innovative agro-industrial enterprises in the context of market changes, limited and scarce resources necessary for production. The subject of the research is the mechanism for making optimal management decisions in the process of choosing innovation and investment programs 
Management Theory and Studies for Rural Business and Infrastructure Development

eISSN 2345-0355. 2021. Vol. 43. No. 1: 129 -136

Article DOI: https://doi.org/10.15544/mts.2021.11

for the development of agro-industrial enterprises.

In the research, the following methods of economic phenomena and processes cognition were used: observation - in order to monitor the specific character of the activities of enterprises in the agro-industrial sector; system analysis - to reveal the foundations of the conceptual apparatus of economic analysis of projects on the creation of new or modernization of existing innovative products and projects on the developed innovations intrusion into the market; economicmathematical and experimental modeling - to develop a model for choosing an optimal projects on creating new or diversification of existing innovative products and projects on the developed innovations intrusion into the market with their integral financing through investment projects; abstract-logical method to make conclusions and generalize the methodology for formation of the effective innovation and investment program for the development of agro-industrial production based on the choice of the optimal innovative projects and sources of their investment; graphic method was used for a visual representation of the structure of an innovation and investment program for the development of agro-industrial production.

The model for optimization of the assessment of expediency and perspectives of multidirectional projects on creating innovations, diversification of innovative activities, intrusion of innovations into the market can be used in practical activities of business entities in order to define an adaptive strategy for innovative development and target programs for its financial support in context of scarce resources and market changes in the agricultural market.

\section{Research results and discussion}

Development and implementation of the innovation and investment program that consists of optimal selection of the most effective projects or modernization of existing innovative products and planning their intrusion into the consumer market by determining the optimal financial strategy, is the key to successful and profitable functioning of enterprises in the agro-industrial sector in conditions of uncertainty and imperfect competition (Gryshko, Zos-Kior, Zerniuk, 2018). We think that the process of implementation of the innovation and investment program should be divided into several levels. Each of these levels can be completed with successful implementation or be unpromising. The result depends on a large number of factors that make a positive or negative synergistic effect on enterprises at a certain point of time. We will introduce the compulsory conditions which must be observed by stakeholders in the process of program implementation. In particular, financial resources attracted from venture capital institutions or other investors for the proposed program are segmentally distributed under the following conditions: activity on development of innovations or production diversification according to market conditions and market fluctuations has priority in attracting financial resources. According to the residual principle, the rest of money is directed to projects on intrusion in order to distribute innovative products on the market. The logic of the adherence to these conditions is based on the fact that as a result of the effective commercialization of the innovations in demand, the necessary part of the profit directed to the production diversification projects or modernization of the characteristics of innovative products already produced by an enterprise or to the development of

Copyright (C 2021 Author(s), published by Vytautas Magnus University. This is an open access article distributed under the terms of the Creative Commons Attribution Non-Commercial 4.0 (CC BY-NC 4.0) license, which permits unrestricted use, distribution, and reproduction in any medium provided the original author and source are credited. The material cannot be used for commercial purposes. 
fundamentally new innovations demanded in the market. Thus, covering of financial costs at all stages of innovation is continuous. The simplified structure of the innovation and investment program for the development of agro-industrial production is schematically shown in Figure 1.

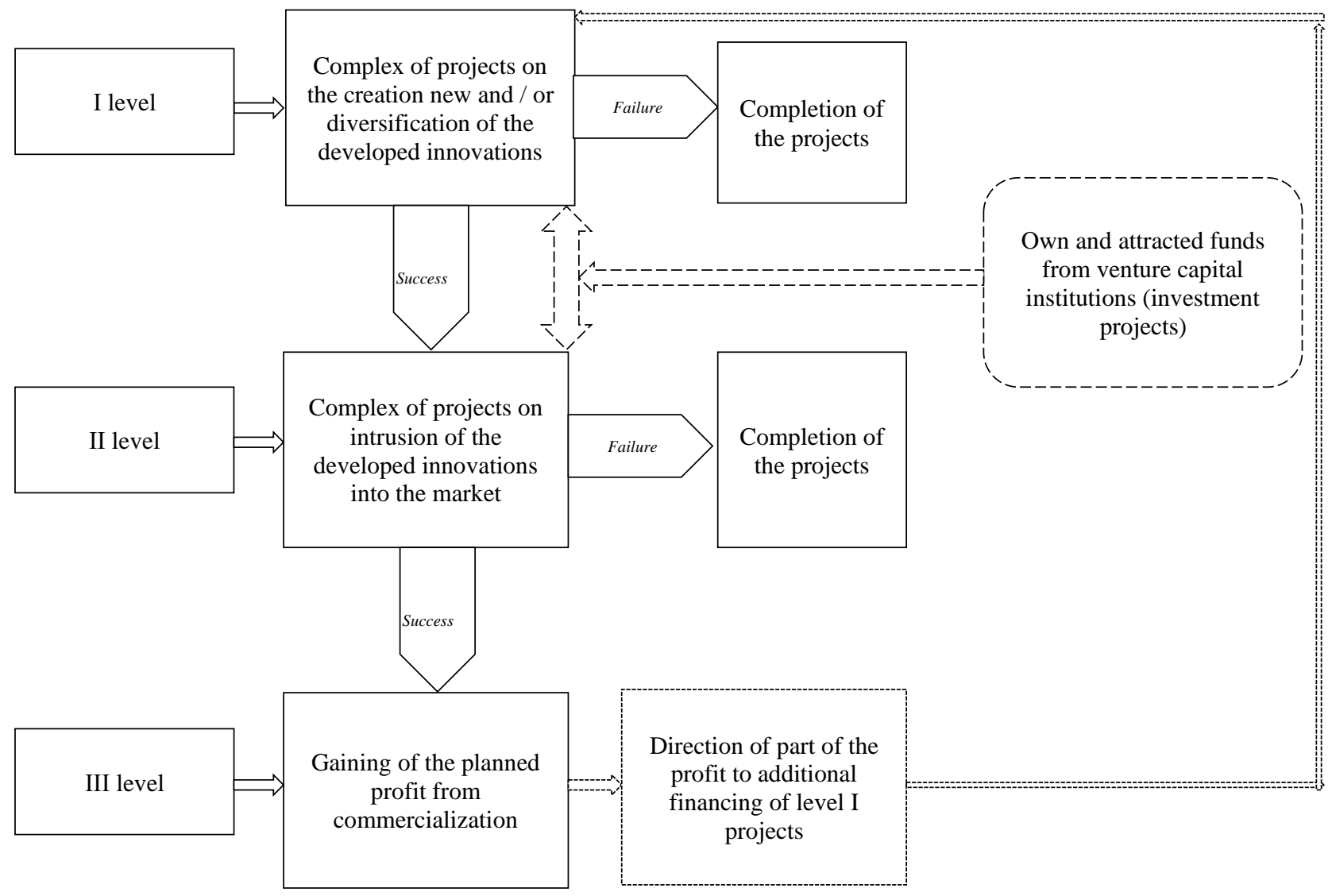

Figure 1. Multilevel structure of implementation of the innovation and investment program for the development of agro-industrial production

It is necessary to determine specific activities in order to optimize the process of implementation of economic and mathematical model of optimal selection of projects on the creation of new or modernization (improvement of certain characteristics) of existing innovative products, projects on the intrusion of the developed innovations into the market with their integral financing.

So, suppose that an enterprise in the agro-industrial sector has planned to implement $n$ variations of investment projects to create innovations or upgrade existing $\left(I_{c r}\right)$, which will be mastered by a stakeholder within a certain period of time $t$ for which a separate cycle of innovation activity takes place. In this case, net discounted income for a separate innovation cycle for each of these projects $\left(N P V_{n}^{I}{ }^{I r r}\right)$ will be calculated by the formula (1):

$$
\begin{aligned}
& N P V_{n}^{I_{c r}} \\
& =-\sum_{t=1}^{n=1} \frac{C_{I n v}^{I_{c r}}}{(1+d)^{t}} \\
& +\sum_{t=1}^{n=1} \frac{C_{\text {Prof }}^{I_{c r}}}{(1+d)^{t}}
\end{aligned}
$$

$C_{I n v}^{I_{c r_{n}}}$ - investments attracted into the activities of an agro-industrial enterprise aimed at implementing the $n$ type project to create new or upgrade existing goods or services;

$C_{P r o f}^{I_{c r_{n}}}$ - income from operating activities received from the implementation of the $n$ type project to create new or upgrade existing goods or services;

$d$ - an interest rate used to recalculate future flows of income into a single current value;

$t$ - a period or a particular innovation cycle expressed in terms of time during which 


\title{
Sciendo
}

\author{
Management Theory and Studies for Rural Business and Infrastructure Development \\ eISSN 2345-0355. 2021. Vol. 43. No. 1: 129 -136 \\ Article DOI: https://doi.org/10.15544/mts.2021.11
}

the $n$ type project is carried out to create new or upgrade existing goods or services.

Taking into account the formula (1), determination of the total coefficient of net discounted income for all given $n$ variations of projects on the creation of new or modernization of existing goods or services $\left(N P V_{I_{c r_{n}}}^{\text {total }}\right)$ and taking into consideration the use of profit share, received from the intrusion of innovative projects into market, as a reserve redistribution, will be the following (2):

$$
\begin{aligned}
N P V_{I_{c r_{n}}}^{\text {total }}=- & \sum_{n=1} F_{\text {add }}^{I_{\text {crn }}} \\
& +\sum_{n=1} N P V_{I_{c r_{n}}}
\end{aligned}
$$

$F_{a d d}^{I_{c r_{n}}}$ - a profit share received by an enterprise from the intrusion of innovative projects into the market, which determines capital redistribution for additional funding of projects to innovate or diversify production (which involves updating the characteristics of goods produced by an enterprise). Moreover, $F_{a d d}^{I_{c r}}$ is calculated as a planned share of net discounted income received by stakeholders from the projects intrusion into the market (3):

$$
F_{\text {add }}^{I_{c r_{n}}}=i * \sum_{k=1} N P V_{\text {Int }_{k}},
$$

$i$ - a share of profit, received by stakeholders from the projects intrusion into the market;

$$
N P V_{\text {Int }_{k}} \text { - an amount of net discounted }
$$

income, received from implementation of $k$ number of projects on intrusion of finished innovations into the market. This index can be calculated by the formula (4):

$$
\begin{aligned}
& N P V_{\text {Int }_{k}} \\
= & -\sum_{t=1}^{k=1} \frac{C_{\text {Inv }^{\text {Int }}}^{I_{k}}}{(1+d)^{t}} \\
& +\sum_{t=1}^{n=1} \frac{C_{\text {Prof }^{\text {Int }}}}{(1+d)^{t}}=> \\
=> & N P V_{\text {Int }_{k}}^{\text {total }_{k}}=\sum_{k=1}^{N P V_{\text {Int }_{k}}}
\end{aligned}
$$

$C_{I n v}^{I_{i n t_{k}}}$ - an amount of financial resources invested in implementation of k-type project on intrusion of the developed innovations into the market;

$$
C_{\text {Prof }}^{I_{\text {int }}} \text { - an amount of operating profit, }
$$
received from implementation of k-type project on the developed innovations intrusion into the market;

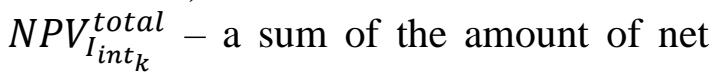
discounted income for all projects on the developed innovations intrusion into the market that have been presented by a stakeholder.

The proposed economic and mathematical model has definite limitations and its implementation involves a sufficient level of cash flows, which an enterprise absorbs throughout the entire innovation cycle (5-6):

$$
\begin{gathered}
N P V_{I_{c r_{n}}}^{\text {total }}+N P V_{\text {Int }_{k}}^{\text {total }} \rightarrow \max \\
\sum_{n=1} C_{\text {Inv }}^{I_{c r_{n}}}+\sum_{\substack{k=1 \\
\leq F_{\text {res }}^{\text {total }}}}^{C_{\text {Inv }}^{I_{\text {int }}},}
\end{gathered}
$$

$F_{\text {res }}^{\text {total }}$-a sufficient level of funds, determined by the successful implementation of investment projects. Sufficient level is the amount of financial resources involved in investment support for innovation, production diversification or for improving the characteristics of finished products $\left(F_{r e s}^{I_{c r}}\right)$ and projects on the innovation intrusion into the consumer market a $\left(F_{\text {res }}^{I_{\text {int }}}\right)(7)$ :

$$
F_{\text {res }}^{\text {total }}=F_{\text {res }}^{I_{\text {cr }}}+F_{\text {res }}^{I_{\text {int }}}
$$

Based on the above-mentioned information, we focus on the application of the proposed model on a specific example. For example, investment funds amounting to $\$ 65$ thousand have been attracted to the innovative activity of an agro-industrial enterprise (of which \$ 40 thousand is for intrusion of innovative projects into the market; \$25

Copyright (C 2021 Author(s), published by Vytautas Magnus University. This is an open access article distributed under the terms of the Creative Commons Attribution Non-Commercial 4.0 (CC BY-NC 4.0) license, which permits unrestricted use, distribution, and reproduction in any medium provided the original author and source are credited. The material cannot be used for commercial purposes. 
thousand is for the implementation of the $n$ type project to create new or diversify production in order to upgrade existing goods or services). It should be noted that a stakeholder needs to make a choice between 5 projects on intrusion into the market in order to implement the proposed model. The implementation period of these projects must be within 7 years. The remaining 4 projects on the creation of innovations or modernization of existing goods or services will be run for 5 years. The discount rate for all projects is $10 \%$. These data are shown in table 1 and table 2.

Table 1. Calculation data on net cash flows of projects on intrusion of finished innovations into the market, thousand \$

\begin{tabular}{|c|c|c|c|c|c|}
\hline \multirow{2}{*}{ Period of time } & \multicolumn{5}{|c|}{ Projects on the intrusion of finished innovations into the market } \\
\cline { 2 - 6 } & $I_{\text {int }_{1}}$ & $I_{\text {int }_{2}}$ & $I_{\text {int }_{3}}$ & $I_{\text {int }_{4}}$ & $I_{\text {int }_{5}}$ \\
\hline$t_{1}$ & -18.00 & -20.00 & - & - & - \\
\hline$t_{2}$ & 15.00 & -5.00 & -12.00 & - & - \\
\hline$t_{3}$ & 10.00 & 19.00 & 10.00 & -6.00 & -20.00 \\
\hline$t_{4}$ & 11.00 & 21.00 & 13.00 & 7.00 & 10.00 \\
\hline$t_{5}$ & 15.00 & 23.00 & 26.00 & 12.00 & 20.00 \\
\hline$t_{6}$ & - & 27.00 & 32.00 & 15.00 & 30.00 \\
\hline$t_{7}$ & - & - & - & 22.00 & 35.00 \\
\hline$N P V_{\text {int }_{k}}$ & 20,35 & 35.56 & 40.42 & 27.32 & 38.85 \\
\hline$N P V_{\text {Intal }_{k}}^{\text {talyyyyy}}$ & \multicolumn{5}{l}{} \\
\hline
\end{tabular}

Taking into account the information given in table 1 and financial sources in the amount of $\$ 40$ thousand to cover intrusion of finished innovations into the market, it is possible to form the optimal complex of projects $I_{\text {int }}, I_{\text {int }_{4}}, I_{\text {int }}$ for the innovation and investment program and receive the net discounted income of \$ 106.59 thousand.

We consider the initial data on the formation of net cash flows of projects to create innovations or upgrade existing ones.

Table 2. Calculation data on net cash flows of projects on the creation of innovations or modernization of existing ones, thousand \$

\begin{tabular}{|c|c|c|c|c|}
\hline \multirow[t]{2}{*}{ Period of time } & \multicolumn{4}{|c|}{$\begin{array}{l}\text { Projects on the creation of innovations or modernization of existing } \\
\text { ones }\end{array}$} \\
\hline & $I_{c r_{1}}$ & $I_{C r_{2}}$ & $I_{c r_{3}}$ & $I_{C r_{4}}$ \\
\hline$t_{1}$ & -7 & -9 & -8 & -6 \\
\hline$t_{2}$ & -1 & -7 & -6 & -6 \\
\hline$t_{3}$ & 12 & 14 & -5 & -1 \\
\hline$t_{4}$ & 17 & 26 & 4 & 9 \\
\hline$t_{5}$ & - & - & 12 & 12 \\
\hline$N P V_{I_{c r_{n}}}$ & 13.36 & 14.18 & -5.85 & 2.37 \\
\hline$F_{a d d}^{I_{c r}}$ & \multicolumn{4}{|c|}{8.1} \\
\hline$N P V_{\text {Int }_{k}}^{\text {total }}$ & \multicolumn{4}{|c|}{18.22} \\
\hline
\end{tabular}

Taking into account the information given in table 2 and financial sources in the amount of $\$ 25$ thousand to cover the projects on the creation of innovations or modernization of existing ones, it is possible to form the optimal complex of projects $I_{c r_{1}}, I_{c r_{2}}$ for the innovation and investment program and receive the net discounted income of $\$ 106.59$ thousand.
Thus, the proposed model allows stakeholders while planning the innovation and investment program for the development of agro-industrial production to redistribute and effectively disburse funds at all stages of innovation activity under changing conditions of the functioning of agro-industrial enterprises. As a result of the calculation of economic and mathematical modeling, the 


\author{
Management Theory and Studies for Rural Business and Infrastructure Development \\ eISSN 2345-0355. 2021. Vol. 43. No. 1: 129 -136 \\ Article DOI: https://doi.org/10.15544/mts.2021.11
}

optimal innovation and investment program has been formed. This program includes the creation of innovations or modernization of existing ones $I_{C r_{1}}, I_{c r_{2}}$, and projects on finished innovations intrusion into the market $I_{\text {int }_{3}}, I_{\text {int }_{4}}, I_{\text {int }_{5}}$. Besides, the total discounted income received from the implementation of this program was $\$ 134.13$ thousand. Projects on creation of innovations or diversification of existing ones provided the sum of $\$ 27.54$ thousand, and projects on the intrusion of finished innovations into the market provided the sum of $\$ 107.59$ thousand.

\title{
Conclusions
}

Management of financial resources during the implementation of projects on the creation of innovations or modernization of existing ones and their effective intrusion into the consumer market will provide agroindustrial enterprises with competitive

\section{References}

Cardoso, H., Gonçalves, A., Carvalho, G., Carvalho, H. (2020). Evaluating innovation development among Brazilian micro and small businesses in view of management level: Insights from the local innovation agents program // Evaluation and Program Planning. Vol.80. - Retrieved from: https://doi.org/10.1016/j.evalprogplan.2020.101797 [26 01 2021].

Collins, J. D., Reutzel, C. R. (2017). The role of top managers in determining investment in innovation: The case of small and medium-sized enterprises in India // International Small Business Journal. Vol.35. No.5:618-638. Retrieved from: https://doi.org/10.1177/0266242616658507 [26 01 2021].

Ganushchak-Efimenko, L., Hnatenko, I., Kozhushko, R., Rębilas, R., Rubezhanska, V., Krakhmalova, T. (2020). Optimization models of investment management in the activities of innovative enterprises // Management Theory and Studies for Rural Business and Infrastructure Development. Vol.42. No.3: 225-234. - Retrieved from: https://doi.org/10.15544/mts.2020.22 [26 01 2021].

Goncharov, V., Zos-Kior, M., Rakhmetulina, Zhibek B. (2013). The investment component of Ukrainian agrarian enterprises' development in conditions of land reform // Actual problems of the economy. Vol.10. No.148: 118-125. [26 $012021]$.

Gryshko, V., Zos-Kior, M., Zerniuk, O. (2018). Integrating the BSC and KPI systems for improving the efficiency of logistic strategy implementation in construction companies // International Journal of Engineering \& Technology. Vol.7. No.3.2: 131-134. - Retrieved from: https://doi.org/10.14419/ijet.v7i3.2.14389 [26 012021$].$

Hnatenko, I., Orlova-Kurilova, O., Shtuler, I., Serzhanov, V., Rubezhanska, V. (2020). An Approach to Innovation Potential Evaluation as a Means of Enterprise Management Improving // International Journal of Supply and Operations Management. Vol.7 No.1: 112-118. - Retrieved from: https://doi.org/10.22034/IJSOM.2020.1.7 [28 10 2020].

Kuksa, I., Hnatenko, I., Orlova-Kurilova, O., Moisieieva, N., Rubezhanska, V. (2019). State regulation of innovative employment in the context of innovative entrepreneurship development // Management Theory and Studies

Copyright (C) 2021 Author(s), published by Vytautas Magnus University. This is an open access article distributed under the terms of the Creative Commons Attribution Non-Commercial 4.0 (CC BY-NC 4.0) license, which permits unrestricted use, distribution, and reproduction in any medium provided the original author and source are credited. The material cannot be used for commercial purposes. 
for Rural Business and Infrastructure Development. Vol.41. No.2: 228-236. - Retrieved from: https://doi.org/10.15544/mts.2019.19 [28 10 2020].

Liu, B., Wang, J., Chan, K. C., Fung, A. (2020). The impact of entrepreneurs's financial literacy on innovation within small and medium-sized enterprises // International Small Business Journal. - Retrieved from: https://doi.org/10.1177/0266242620959073 [26 01 2021].

Luo, J., Guo, H., Jia, F. (2017). Technological innovation in agricultural co-operatives in China: Implications for agro-food innovation policies // Food Policy. Vol.73:19-33. - Retrieved from: https://doi.org/10.1016/j.foodpol.2017.09.001 [26 01 2021].

Martins, P. (2017). Integrating financial planning, loaning strategies and project scheduling on a discrete-time model // Journal of Manufacturing Systems. Vol.44:217-229. - Retrieved from: https://doi.org/10.1016/j.jmsy.2017.06.001 [26 01 2021].

Samborskyi, O., Isai, O., Hnatenko, I., Parkhomenko, O., Rubezhanska, V., Yershova, O. (2020). Modeling of foreign direct investment impact on economic growth in a free market // Accounting. Vol.6. No.5: 705-712. - Retrieved from: https://doi.org/10.5267/j.ac.2020.6.014 [28 10 2020].

Shahbaz, M., Raghutla, C., Song, M., Zameer, H., Jiao, Z. (2020). Public-private partnerships investment in energy as new determinant of $\mathrm{CO} 2$ emissions: The role of technological innovations in China // Energy Economics. Vol.86. Retrieved from: https://doi.org/10.1016/j.eneco.2020.104664 [26 01 2021].

Stevanato, N., Lombardi, F., Guidicini, G., Rinaldi, L., Balderrama, S., Pavičević, M., Quoilin S., Colombo, E. (2020). Long-term sizing of rural microgrids: Accounting for load evolution through multi-step investment plan and stochastic optimization // Energy for Sustainable Development. Vol.58:16-29 - Retrieved from: https://doi.org/10.1016/j.esd.2020.07.002 [26 01 2021].

Zos-Kior, M., Hnatenko, I., Isai, O., Shtuler, I., Samborskyi, O., Rubezhanska, V. (2020). Management of efficiency of the energy and resource saving innovative projects at the processing enterprises // Management Theory and Studies for Rural Business and Infrastructure Development. Vol.42. No.4:504-515. - Retrieved from: https://doi.org/10.15544/mts.2020.52 [26 012021$]$. 